\title{
Topically Used Herbal Products for the Treatment of Psoriasis - Mechanism of Action, Drug Delivery, Clinical Studies
}

Authors

Affiliations
Anna Herman ${ }^{1}$, Andrzej P. Herman ${ }^{2}$

${ }^{1}$ Faculty of Cosmetology, The Academy of Cosmetics and Health Care, Warsaw, Poland

${ }^{2}$ Laboratory of Molecular Biology, The Kielanowski Institute of Animal Physiology and Nutrition, Polish Academy of Sciences, Jabłonna, Poland
Key words

- Psoriasis

- herbal products

- keratinocyte hyperproliferation

- inflammatory reaction

- skin barrier

- herbal drug delivery systems received May 23, 2016

revised July 31, 2016

accepted August 8, 2016

Bibliography

DOI http://dx.doi.org/

10.1055/s-0042-115177

Published online August 30,

2016

Planta Med 2016; 82:

1447-1455 @ Georg Thieme

Verlag KG Stuttgart · New York ·

ISSN 0032-0943

\section{Correspondence}

Anna Herman, PhD, DSc, Prof.

Faculty of Cosmetology

The Academy of Cosmetics and

Health Care

Podwale 13 street

00-252 Warsaw

Poland

Phone: + 48226355009

Fax: +48226357362

anna.herman@onet.pl

\section{Abstract \\ $\nabla$}

Psoriasis is a chronic inflammatory skin disease characterized histologically by hyperproliferation and aberrant differentiation of epidermal keratinocytes. A wide range of conventional medical therapies to treat psoriasis is established, from topical therapies and systemic medications through to phototherapy or combinations of those. However, most of these therapies have a limited efficacy and may cause a number of side effects, including cutaneous atrophy, organ toxicity, carcinogenicity, and broadband immunosuppression, which are restricting their long-term use. Therefore, it would be desirable to use herbal products as an alternative treatment for psoriasis that causes fewer side effects. For this purpose,

\section{Introduction}

\section{$\nabla$}

Psoriasis is a chronic autoimmune human skin disorder that is characterized by excessive proliferation of keratinocytes, scaly plaques, severe inflammation, and erythema [1]. A wide range of conventional medical therapies to treat psoriasis is established, from topical therapies [steroids, vitamin D analogues, psoralen, 5-aminolevulinic acid, salicylates, fumaric acid esters, anthralins (dithranol), tacrolimus, retinoids - e.g tazarotene] and systemic medications (methotrexate, cyclosporine, retinoids, 6-thioguanine, mycophenolate mofetil, troglitazone and new biologic agents, such as adalimumab, alefacept, efalizumab, etanercept, infliximab), through to phototherapy or combinations of those [2]. However, most of these therapies cause a number of side effects, and limited in efficacy, inconvenience, cutaneous atrophy, organ toxicity (hepatotoxicity, nephrotoxicity, teratogenicity), carcinogenicity, and broadband immunosuppression, which are limiting their long-term use $[3,4]$. In turn, a short-term several electronic databases and literature references were used to summarize the current knowledge acquired on the basis of animal studies and clinical trials regarding herbal products used to treat psoriasis topically. This review discusses the mechanisms of herbal products activities through (1) inhibition of the keratinocyte hyperproliferation and inducing apoptosis, (2) inhibition of immune-inflammatory reaction, (3) suppression of phosphorylase kinase $(\mathrm{PhK})$ activity, and (4) inhibition of the hedgehog ( $\mathrm{Hh}$ ) signaling pathway. Moreover, the penetration of herbal products through the psoriatic skin barrier, novel herbal drug delivery systems in psoriasis treatment, and possible adverse effects of herbal therapy are discussed. treatment of psoriasis causes its remission after finishing the treatment or only relieves the patient's condition. Moreover, psoriasis is often accompanied by other diseases, such as depressive illness, cardiovascular disease, and a seronegative arthritis known as psoriatic arthritis [5]. Therefore, the invention of new alternative treatments for psoriasis causing fewer side effects would be desirable. It seems that several herbal drugs can meet these requirements and have to be seen as promising new agents for psoriasis treatment [6]. Herbal products are greatly accepted by patients because they are believed to be safer than conventional therapeutics. Moreover, herbal products present a great structural diversity and multidirectional mechanisms of action, which is not commonly seen in synthetic compounds. Herbal drugs may become an effective treatment for psoriasis, causing lower costs and less side- or toxic effects in comparison to other therapies. Therefore, researchers are still looking for novel herbal products and/or their active constituents, 
which potentially could be used for the treatment of psoriasis instead of synthetic drugs.

The goal of this review is to summarize the knowledge based on animal studies and clinical trials regarding herbal products used for the topical treatment of psoriasis and to characterize their mechanisms of action. Penetration of herbal products through the psoriatic skin barrier, novel herbal drug delivery systems in psoriasis treatment, and possible adverse effects of herbal therapy are also discussed.

\section{Methods \\ $\nabla$}

\section{Search strategy}

PubMed, Scopus and Google Scholar were searched for articles published from 1995 up to the present. Search terms included "herbal products and psoriasis", "herbal treatments for psoriasis", "topical herbal medication for psoriasis", and "herbal drug delivery systems in psoriasis treatment". References from reviews about herbal products and psoriasis were examined for additional articles and case reports. A manual search was also conducted, based on citations in scientific literature.

\section{Inclusion and exclusion criteria}

Selection criteria included articles which are examining herbal products used for the topical treatment of psoriasis by means of animal studies and clinical trials, and are comparing herbal products treatment vs. control treatments (placebo or active therapy). Other forms of psoriasis treatment than topical administration of herbal products (e.g. oral, systemic) were excluded from the study. Also publications in languages other than English were excluded.

\section{Pathology of Psoriasis}

The pathophysiology of psoriasis involves both skin cells and immune cells. Psoriasis is typically characterized as inflamed skin with surface scales, thickening of the epidermis (acanthosis; granular layer is reduced or absent) caused by parakeratosis, which is a consequence of nuclei retention in SC keratinocytes caused by abnormal differentiation and hyperproliferation of epidermal keratinocytes $[1,7]$. Some scientific reports consider nitric oxide (NO), released from keratinocytes at high concentrations, as a key inhibitor of cellular proliferation and inducer of cell differentiation in vitro. Although a high-output NO synthesis is suggested by the expression of inducible NO synthase (iNOS), mRNA, and proteins in psoriasis lesions, the pronounced hyperproliferation of psoriatic keratinocytes may indicate that iNOS activity is too low to effectively deliver antiproliferative NO concentrations [8]. As a consequence, the impairment of corneocyte differentiation, including an impaired formation and secretion of lamellar body contents and the processing of lamellar body contents into lamellar bilayers, causes a reduction in the psoriatic skin barrier function [9]. Moreover, skin barrier problems in psoriasis are not only the excessive growth and aberrant differentiation of corneocytes but also almost absent normal moisturizing factors (NMFs) like water, an imbalance of skin lipids (rise in the levels of cholesterol and fall in the levels of ceramides), and dry and sensitive skin [10].

The role of the immune system and its interactive network of leukocytes and cytokines in disease pathogenesis was also described $[11,12]$. Psoriatic lesions are highly infiltrated with immune cells, most notably $\mathrm{CD}^{+} \mathrm{T}$ cells and $\mathrm{CD} 11 \mathrm{c}^{+}$dendritic cells $[13,14]$.
Proinflammatory cytokines produced by these cells, including tumor necrosis factor- $\alpha$ (TNF- $\alpha$ ), interferon- $\gamma$ (IFN- $\gamma$ ), interleukin17 (IL-17), IL-20, IL-22, IL-23, IL-12, and IL-1b, have been linked to the pathogenesis of psoriasis through causing keratinocytes hyperproliferation [7]. Moreover, IFN- $\gamma$ and IL-15 seem to increase the apoptotic resistance of the keratinocytes [15,16]. Also growth factors and genetic factors like transforming growth factor (TGF)- $\beta$, toll-like receptor (TLR)-2, signal transducer and activator of transcription (STAT-3), coiled-coil alpha-helical rod protein 1 (CCHCR1), steroidogenic acute regulatory protein (StAR), and vitamin D receptor (VDR) are suggested to be the most critical factors governing the exacerbation of psoriasis $[17,18]$. The essential transcription factor in psoriasis, nuclear factor kappa B (NF- $k \mathrm{~B})$, has been shown to be a key regulatory element occurring in a variety of immune and inflammatory pathways, in cellular proliferation and differentiation, and in apoptosis [19]. An imbalance between the proapoptotic and antiapoptotic activities of NF- $k$ B proteins has been demonstrated to cause differentiation and hyperproliferation in psoriatic lesions rather than in normal cells [20].

\section{Topically Used Herbal Products for the Treatment of Psoriasis}

Many herbal topical formulations have been marketed worldwide to prevent psoriasis [21]. There are many advantages of using natural drugs, including patient compliance, less side-effects, easy availability, low-costs, and more than one mode of biochemical action for psoriasis treatment. Therefore, researchers are searching for new herbal products, which have the potential to be an alternative for synthetic drugs in psoriasis therapy.

\section{Animal-based studies}

Herbal products with an anti-psoriasis potential tested in animalbased studies are summarized in $\bullet$ Table 1. Most of the in vivo studies performed in animals are based on a mouse tail model of psoriasis, introduced by Jarrett and Spearman [22]. The model is based on the induction of orthokeratosis in those parts of the adult mouse tail, which have normally a parakeratotic differentiation. Antipsoriatic drug activity is defined by the percentage increase of orthokeratotic regions after topical drug treatment of a mouse tail. Ethanolic extract of Aloe vera leaf gel [23], ethanolic extract of Nigella sativa [24], ethanolic extract of Rubia cordifolia [25], methanol extract of Smilax china and the isolated flavonoid quercetin [26], Thespesia populne extract [27], hydro alcoholic extract of Wrightia tinctoria [28], and baicalin isolated from Scutellaria baicalensis [29] were assessed for their antipsoriatic activity using the mouse tail model. All of them exhibited a significant percentage reduction of relative epidermal thickness, promoted epidermal differentiation and normal keratization of keratinocyte, produced significant orthokeratosis, and exhibited a higher antipsoriatic activity as the positive control (tretinoin $0.05 \%$, tazarotene $0.1 \%$, dithranol $1 \%$, tacrolimus $0.03 \%$, retinoic acid). A topically administered ointment containing methanol extract of Kigelia africana induced a significant and dose-dependent increase in orthokeratosis in parakeratotic areas of albino mouse tails, with significant effects on the epidermal thickness compared to the vehicle control [30].

Only two studies were based on an UVB-induced model of psoriasis. UVB-induced photodermatitis in rats has been proposed as an experimental model for Psoriasis vulgaris by Nagakuma et al. [32]. The model is based on the induction of dark-brown scale on the erythematous lesion after UVB irradiation. Singhal and Kan- 
Table 1 Herbal products used for the topical treatment of psoriasis - animal studies.

\begin{tabular}{|c|c|c|c|c|c|}
\hline Plant & Animal & $\begin{array}{l}\text { Model of } \\
\text { the study }\end{array}$ & Pharmacological data & Effect & Ref. \\
\hline Cassia tora & $\begin{array}{l}\text { albino } \\
\text { mice }\end{array}$ & $\begin{array}{l}\text { UVB- } \\
\text { induced } \\
\text { psoriasis }\end{array}$ & $\begin{array}{l}\text { methanolic } C \text {. tora extract }(0.05 \%, 0.1 \%, 0.2 \%) \text { in } \mathrm{O} / \mathrm{W} \text { creams; } \\
\text { positive control: tretinoin }(0.05 \%) \text { in base cream; } \\
\text { treatment: single dose of creams with different concentrations } \\
\text { of extract/tretinoin/cream base/crude extract }\end{array}$ & $\begin{array}{l}\text { O/W creams with extracts exhibited a } \\
\text { significant reduction in percentage of } \\
\text { relative epidermal thickness as compared } \\
\text { to tretinoin }\end{array}$ & [31] \\
\hline $\begin{array}{l}\text { Kigelia } \\
\text { africana } \\
\text { (sausage } \\
\text { tree) }\end{array}$ & $\begin{array}{l}\text { albino } \\
\text { mice }\end{array}$ & $\begin{array}{l}\text { mouse tail } \\
\text { model of } \\
\text { psoriasis }\end{array}$ & $\begin{array}{l}\text { ointments containing } 200,100 \text { and } 50 \mathrm{mg} / \mathrm{ml} \text { of methanol } \\
\text { extracts from stem, leaves, and fruit of } K \text {. africana; } \\
\text { control: vehicle and placebo; } \\
\text { treatment: } 0.1 \mathrm{ml} \text { of the ointment, contact time of } 2-3 \mathrm{~h} \text {, } \\
\text { once daily for } 2 \text { weeks }\end{array}$ & $\begin{array}{l}\text { stem methanol extracts induced ortho- } \\
\text { keratosis in parakeratotic areas of mouse } \\
\text { tail with significant effects on epidermal } \\
\text { thickness }\end{array}$ & [30] \\
\hline Nigella sativa & $\begin{array}{l}\text { albino } \\
\text { mice }\end{array}$ & $\begin{array}{l}\text { mouse tail } \\
\text { model of } \\
\text { psoriasis }\end{array}$ & $\begin{array}{l}95 \% \text { ethanolic extract of } N \text {. sativa desolved in water; ratio } 1: 2 \text {; } \\
\text { control: placebo; } \\
\text { positive control: tazarotene gel }(0.1 \%) \text {; } \\
\text { treatment: once daily for } 14 \text { days, contact with the skin for } 2 \mathrm{~h}\end{array}$ & $\begin{array}{l}\text { extract produced equivalent epidermal } \\
\text { differentiation in degree of orthokerato- } \\
\text { sis as tazarotene }\end{array}$ & [24] \\
\hline $\begin{array}{l}\text { Rubia } \\
\text { cordifolia }\end{array}$ & $\begin{array}{l}\mathrm{BALB} / \mathrm{c} \\
\text { mice }\end{array}$ & $\begin{array}{l}\text { mouse tail } \\
\text { model of } \\
\text { psoriasis }\end{array}$ & $\begin{array}{l}\text { ethanolic extract was fractioned sequentially with hexane, } \\
\text { ethyl acetate (EA), n-butanol, and water; } \\
1 \%, 2 \% \text { and } 5 \% \text { EA fraction of extract was formulated into gel; } \\
\text { control: placebo; } \\
\text { positive control: } 1 \% \text { w/w dithranol in gel; } \\
\text { treatment: twice a day, } 7 \text { times a week for } 4 \text { consecutive weeks }\end{array}$ & $\begin{array}{l}\text { EA fraction dose-dependently increased } \\
\text { granular layer and epidermal thickness; } \\
\text { potency of keratinocyte differentiation } \\
5 \% \text { EA fraction is similar to that of dithra- } \\
\text { nol gel }\end{array}$ & [25] \\
\hline $\begin{array}{l}\text { Scutellaria } \\
\text { baicalensis }\end{array}$ & $\begin{array}{l}\mathrm{BALB} / \mathrm{c} \\
\text { mice }\end{array}$ & $\begin{array}{l}\text { mouse tail } \\
\text { model of } \\
\text { psoriasis }\end{array}$ & $\begin{array}{l}\text { creams with } 1 \%, 3 \% \text { and } 5 \% \text { baicalin isolated from S. baicalensis; } \\
\text { control: placebo; } \\
\text { negative control: } 2,4 \text {-dinitrofluorobenzene-induced contact } \\
\text { hypersensitivity (CHS); } \\
\text { positive control } 1: 0.1 \% \text { tazarotene cream; } \\
\text { positive control } 2: 0.03 \% \text { tacrolimus ointment; } \\
\text { treatment: twice daily for } 4 \text { weeks }\end{array}$ & $\begin{array}{l}\text { creams with baicalin inhibit CHS reaction } \\
\text { at a less significant magnitude than that } \\
\text { of tacrolimus ointment; } \\
5 \% \text { baicalin cream promotes epidermal } \\
\text { differentiation and normal keratization } \\
\text { of keratinocyte in mouse similar to that } \\
\text { of tazarotene cream }\end{array}$ & [29] \\
\hline Smilax china & $\begin{array}{l}\text { Swiss } \\
\text { albino } \\
\text { mice }\end{array}$ & $\begin{array}{l}\text { mouse tail } \\
\text { model of } \\
\text { psoriasis }\end{array}$ & $\begin{array}{l}\text { methanol extract and isolated flavonoid quercetin; } \\
\text { positive control: retinoic acid }\end{array}$ & $\begin{array}{l}\text { flavonoid quercetin shows significant } \\
\text { orthokeratosis, anti-inflammatory, and } \\
\text { maximum antiproliferant activities }\end{array}$ & [26] \\
\hline $\begin{array}{l}\text { Thespesia } \\
\text { populne }\end{array}$ & $\begin{array}{l}\text { Wistar } \\
\text { rats }\end{array}$ & $\begin{array}{l}\text { mouse tail } \\
\text { model of } \\
\text { psoriasis }\end{array}$ & $\begin{array}{l}\text { cream with } 100 \mathrm{mg} \text { of each extract (ethanolic, pet-ether, bu- } \\
\text { tanolic, ethyl acetate) and } 50 \mathrm{mg} \text { of each isolated compound } \\
\text { (TpF- } 1 \text { and TpF- } 2 \text { as flavonoids, TpS- } 2 \text { as sterole); } \\
\text { positive control: } 0.05 \% \text { tretinoin cream; } \\
\text { treatment: once daily, } 5 \text { times a week for } 2 \text { weeks }\end{array}$ & $\begin{array}{l}\text { pet-ether extract and TpF-2 increased } \\
\text { orthokeratotic region }\end{array}$ & [27] \\
\hline $\begin{array}{l}\text { Wrightia tinc- } \\
\text { toria }\end{array}$ & $\begin{array}{l}\text { albino } \\
\text { mice }\end{array}$ & $\begin{array}{l}\text { mouse tail } \\
\text { model of } \\
\text { psoriasis }\end{array}$ & $\begin{array}{l}\text { hydro alcoholic extract of } W \text {. tinctoria leaves; } \\
\text { control: vehicle; } \\
\text { positive control: isoretinoic acid; } \\
\text { treatment: once daily for } 14 \text { days }\end{array}$ & $\begin{array}{l}\text { extract produced significant degree of } \\
\text { orthokeratosis compared to isoretinoic } \\
\text { acid and increased the epidermal thick- } \\
\text { ness compared to control }\end{array}$ & [28] \\
\hline
\end{tabular}

sara [31] showed antipsoriatic activities of O/W creams containing methanolic extract of Cassia tora leaves as well as of the crude extract, by using UVB-induced psoriasis in rats. Both of them exhibited a significant percentage reduction of relative epidermal thickness and spleen index as compared to $0.05 \%$ tretinoin as positive control. Also irradiated rat skin treated with SUEX GEL containing aqueous extract of the bark of Pongamia pinnata showed a significant reduction in the total epidermal thickness and retention of the Stratum granulosum compared to ointment base and placebo group [33]. However, there is no animal model that could replace clinical studies. Moreover, positive results of animal-based studies are not always proved in clinical trials. They can only help in the initial determination of new herbal products, which may proceed to further stages of clinical trials and become useful drugs for the treatment of psoriasis in the future.

\section{Clinical studies}

Herbal products with anti-psoriasis potential tested in clinical studies are listed in 0 Table 2. Topical application of cream with 10\% Mahonia aquifolium extract [34], 0.03\% Camptotheca acuminata nut [35], Aloe vera extract [36], oleoresin from Copeifera langsdorffii (5\%) ointment [37], and cream with Persea americana oil [38] showed significantly greater improvements in psoriatic treatment compared with calcipotriol and fluticasone propionate mixture, hydrocortisone, triamcinolone acetonide, and calcipotriol ointment, respectively. In turn, Aloe vera cream [39], Baphicacanthus cusia ointment [40], Camptotheca acuminata nut extract in tincture/gel/ointment [41], Curcuma longa microemulgel [42], Hypericum perforatum ointment [43], Indigo naturalis ointment [44], Indigo naturalis extract in oil [45], Mahonia aquifolium cream [46], Mahonia aquifolium bark extract ointment [47], Strobilanthes formosanus ointment [48], and cream with capsaicin from Capsicum frutescens [49] were found to be significantly more effective than the vehicle control group. There are also literature data showing no significant difference between herbal products and drug/placebo treatment. The effect of Mahonia aquifolium ointment appears to be less potent than that of dithranol [50]. Aleurites moluccana (Kukui nut) oil [51], Aloe vera gel [52], as well as ointment and lotion containing $20 \%$ kunzea oil [53] showed no significant difference compared to a placebo psoriasis treatment.

The clinical studies presented in 0 Table 2 contain some shortcomings, which ultimately do not diminish the value of these limited research works. @ Table 2 reports 10 clinical trials, which 
Table 2 Herbal products used for the topical treatment of psoriasis - clinical studies.

\begin{tabular}{|c|c|c|c|c|c|}
\hline Plant & Type of clinical study & Participants & Treatments & Effect & Ref. \\
\hline Aloe vera & $\begin{array}{l}\text { placebo-controlled, } \\
\text { double-blind clinical } \\
\text { trial }\end{array}$ & $\begin{array}{l}60 \text { patients } \\
\text { (18-50 years) with } \\
\text { slight to moderate } \\
\text { chronic plaque psori- } \\
\text { asis and PASI scores } \\
\text { between } 4.8-16.7\end{array}$ & $\begin{array}{l}\text { A. vera extract }(0.5 \%) \text { in hydrophilic } \\
\text { cream }(n=30) \text {; } \\
\text { base cream }(n=30) \text {; } \\
3 \text { times daily (without occlusion) } \\
\text { for } 5 \text { consecutive days per week for } \\
16 \text { weeks }\end{array}$ & $\begin{array}{l}\text { A. vera cream had cured } 25 / 30 \text { pa- } \\
\text { tients compared to the placebo } \\
\text { cure rate of } 2 / 30 \text { resulting in sig- } \\
\text { nificant clearing of the psoriatic } \\
\text { plaques and decreased PASI score } \\
\text { to a mean of } 2.2\end{array}$ & [39] \\
\hline Aloevera & $\begin{array}{l}\text { randomized, compara- } \\
\text { tive, double-blind clini- } \\
\text { cal trial }\end{array}$ & $\begin{array}{l}80 \text { patients with mild } \\
\text { to moderate plaque } \\
\text { psoriasis }\end{array}$ & $\begin{array}{l}\text { A. vera cream (70\% aloe mucilage) } \\
(n=40) ; \\
\quad 0.1 \% \text { triamcinolone acetonide cream } \\
(n=40) ; \\
\text { twice daily for } 8 \text { weeks }\end{array}$ & $\begin{array}{l}\text { A. vera cream was found to be } \\
\text { more effective than triamcinolone } \\
\text { acetonide cream }\end{array}$ & [36] \\
\hline $\begin{array}{l}\text { Baphicacan- } \\
\text { thus cusia }\end{array}$ & $\begin{array}{l}\text { vehicle-controlled } \\
\text { clinical trial }\end{array}$ & $\begin{array}{l}14 \text { patients with } \\
\text { chronic plaque } \\
\text { psoriasis }\end{array}$ & $\begin{array}{l}\text { indigo naturalis ointment } \\
\text { ( } 20 \% \text { B. cusia powder); } \\
\text { vehicle ointment; } \\
\text { once daily for } 8 \text { weeks }\end{array}$ & $\begin{array}{l}\text { significant reduction of psoriasis } \\
\text { compared to control }\end{array}$ & [40] \\
\hline $\begin{array}{l}\text { Capsicum } \\
\text { frutescens }\end{array}$ & $\begin{array}{l}\text { comparative, vehicle- } \\
\text { controlled, double- } \\
\text { blind clinical trial }\end{array}$ & $\begin{array}{l}44 \text { patients with } \\
\text { moderate to severe } \\
\text { psoriasis }\end{array}$ & $\begin{array}{l}\text { cream with capsaicin isolated from } \\
\text { C. frutescens; } \\
\text { vehicle cream; } \\
\text { once a day for } 6 \text { weeks }\end{array}$ & $\begin{array}{l}\text { capsaicin cream was found to be } \\
\text { significantly more effective than } \\
\text { control }\end{array}$ & [49] \\
\hline Curcuma longa & $\begin{array}{l}\text { randomized, prospec- } \\
\text { tive intra-individual, } \\
\text { right-left comparative, } \\
\text { placebo-controlled, } \\
\text { double blind clinical trial }\end{array}$ & $\begin{array}{l}40 \text { patients } \\
\text { ( } 18-60 \text { years) with } \\
\text { mild to moderate } \\
\text { plaque psoriasis }\end{array}$ & $\begin{array}{l}\text { turmeric (hydroalcoholic C. longa } \\
\text { extract) microemulgel; } \\
\text { twice a day for } 9 \text { weeks }\end{array}$ & $\begin{array}{l}\text { progressive reduction of thickness, } \\
\text { followed by decrease erythema, } \\
\text { pruritus, resulting in moderate to } \\
\text { acceptable improvement; } \\
\text { in some cases, significant resolu- } \\
\text { tion of psoriatic lesions }\end{array}$ & [42] \\
\hline $\begin{array}{l}\text { Hypericum per- } \\
\text { foratum }\end{array}$ & $\begin{array}{l}\text { right-left comparative, } \\
\text { vehicle- controlled, } \\
\text { single blinded (only } \\
\text { patients were blinded) } \\
\text { clinical trial }\end{array}$ & $\begin{array}{l}10 \text { patients } \\
\text { ( } 20-55 \text { years) with } \\
\text { mild plaque psoriasis }\end{array}$ & $\begin{array}{l}\text { H. perforatum ( } 5 \% \text { ) ointment; } \\
\text { vehicle ointment; } \\
\text { twice daily for } 4 \text { weeks }\end{array}$ & $\begin{array}{l}\text { improvement in clinical scores } \\
\text { was reported with } \mathrm{H} \text {. perforatum } \\
\text { ointment compared with placebo } \\
\text { group }\end{array}$ & [43] \\
\hline Indigo naturalis & $\begin{array}{l}\text { randomized, vehicle- } \\
\text { controlled, observer- } \\
\text { blind clinical trial }\end{array}$ & $\begin{array}{l}31 \text { patients with sym- } \\
\text { metrically compara- } \\
\text { ble psoriatic nails }\end{array}$ & $\begin{array}{l}\text { refined I. naturalis extract in oil } \\
\text { (Lindioil); } \\
\text { olive oil; } \\
\text { twice daily for the first } 24 \text { weeks }\end{array}$ & $\begin{array}{l}\text { reduction of NAPSI scores for the } \\
\text { Lindioil group was superior to the } \\
\text { reduction in the control group }\end{array}$ & [45] \\
\hline $\begin{array}{l}\text { Mahonia } \\
\text { aquifolium }\end{array}$ & $\begin{array}{l}\text { placebo-controlled, } \\
\text { double-blind clinical } \\
\text { trial }\end{array}$ & $\begin{array}{l}200 \text { patients with } \\
\text { mild to moderate } \\
\text { psoriasis }\end{array}$ & $\begin{array}{l}\text { cream with } 10 \% \text { M. aquifolium } \\
\text { extract; } \\
\text { twice a day for } 12 \text { weeks }\end{array}$ & $\begin{array}{l}\text { significant improvements in PASI } \\
\text { and QLI in the Mahonia-treated } \\
\text { group compared with the control } \\
\text { group }\end{array}$ & [46] \\
\hline $\begin{array}{l}\text { Strobilanthes } \\
\text { formosanus }\end{array}$ & $\begin{array}{l}\text { randomized, vehicle- } \\
\text { controlled, observer- } \\
\text { blind clinical trial }\end{array}$ & $\begin{array}{l}42 \text { patients with } \\
\text { chronic plaque } \\
\text { psoriasis }\end{array}$ & $\begin{array}{l}\text { - indigo naturalis ( } 1.4 \% \text { ) ointment; } \\
\text { - vehicle ointment; } \\
\text { once a day for } 12 \text { weeks }\end{array}$ & $\begin{array}{l}31 \text { of } 42 \text { patients experienced } \\
\text { clearance or near clearance of } \\
\text { psoriasis after herbs ointment } \\
\text { treatment }\end{array}$ & [48] \\
\hline $\begin{array}{l}\text { Persea } \\
\text { americana } \\
\text { (Avocado) }\end{array}$ & $\begin{array}{l}\text { randomized, prospec- } \\
\text { tive, right-left compar- } \\
\text { ative clinical trial }\end{array}$ & $\begin{array}{l}13 \text { patients ( } 10 \text { men } \\
\text { and } 3 \text { women) with } \\
\text { chronic plaque psori- } \\
\text { asis }\end{array}$ & $\begin{array}{l}\text { cream with vitamin } \mathrm{B} 12 \text { and avocado } \\
\text { oil; } \\
\text { t vitamin } \mathrm{D}_{3} \text { analog calcipotriol; } \\
\text { twice daily for } 12 \text { weeks }\end{array}$ & $\begin{array}{l}\text { cream with vitamin B12 and avo- } \\
\text { cado oil was effective as calcipo- } \\
\text { triol cream with regard to PASI } \\
\text { score }\end{array}$ & [38] \\
\hline
\end{tabular}

PASI - Psoriasis Area and Severity Index; QLI - Quality of Life Index; NAPSI - Nail Psoriasis Severity Index

were carried out on groups consisting of $10-20$ patients $(3 / 10)$, $30-50$ patients $(4 / 10), 60-80$ patients $(2 / 10)$, and more than 100 patients $(1 / 10)$. In practice, the first phase of clinical trials involved usually 100-500 participants, because only studies carried out with more than 100 patients provide the opportunity for statistical analyses. Only one of the above described clinical trials was performed on 200 subjects. The participants in this randomized, double-blind, placebo-controlled study used either the topical cream Reliéva (a homeopathic product containing a proprietary M. aquifolium extract) or control (placebo) [46]. Other clinical trials included a nonrepresentative number of participants and therefore the conclusions of these studies cannot be generalized to the entire population affected by psoriasis. Moreover, participants (men and women) aged from 18 to 60 years with mild chronic plaque psoriasis $(1 / 10)$, mild to moderate chronic plaque psoriasis $(4 / 10)$, moderate to severe chronic plaque psoriasis (1/10), and chronic plaque psoriasis without determining psoriasis area (4/10) were condensed in clinical trials. Plaque psoriasis, also known as Psoriasis vulgaris, affects about $90 \%$ of all cases of psoriasis, which makes the described research potentially useful to treat this type of psoriasis. These clinical studies included randomized trials (5/10), vehicle-controlled $(8 / 10)$, comparative $(5 / 10)$, observer-blind $(2 / 10)$, single-blind $(1 / 10)$, and double-blind clinical trials $(5 / 10)$. It is known that only well-controlled double-blind clinical trials can prove the efficacy of herbal products in psoriasis treatment. Moreover, such research is expensive, long lasting and requires a special permission from the regulatory authorities. Also compared to multi- 
directional synthetic drug studies, clinical and toxicological studies to prove the efficacy and safety of herbal products are rare. Several factors might contribute to the explanation of such discrepancies, for example a lack of standardization and quality control of the herbal products used in clinical trials, the use of different dosages of herbal medicines, inadequate randomization in most studies and an improper selection of patients, the numbers of patients in most trials are insufficient for the attainment of statistical significance, wide variations in the duration of treatments using herbal medicines, and lacking or insufficient results of toxicological studies. Unfortunately, the most of the above-mentioned factors can be related to the clinical trials described in - Table 2.

\section{Herbal Products Penetration Through Psoriasis Skin}

Novel drug delivery systems such as liposome, niosome, ethosome, microemulsion, nanoemulsion, solid lipid nanoparticles (SLNs), and nanostructured lipid carrier systems (NLCs) present desirable attributes for the use in extremely dehydrated and thickened psoriatic skin that has a lipid imbalance and is sensitive to irritants $[54,55]$. They offer an enhanced penetration through skin with less toxic effects compared to free drugs (liposomes), slow down drug release and reduce systemic toxicity (niosomes), enable drugs to reach the deep skin layers and/or the systemic circulation (ethosomes), provide long-term stability and high solubilization capacity for hydrophilic and lipophilic drugs (microemulsions), prolonge action on the skin and protect the drug from instability (nanoemulsions), cause only negligible skin irritation, and ensure the compatibility of the drugs (NLCs) [54]. Moreover, topical drug delivery systems with herbal formulations enhance the therapeutic effects of herbal drugs and facilitate their penetration through the skin $[56,57]$.

Studies performed on liposomal vesicles (combination of methotrexate and menthol) incorporated in vesicular gel base [58], elastic liposomal formulation of colchicine isolated from Colchicum autumnale and Gloriosa superb [59], and capsaicin-containing liposomes, niosomes and emulsomes [60] confirmed their potential to enhance skin accumulation, prolong drug release, and improve the site-specificity of active constituents as effective drugs in the treatment of psoriasis. Niosomes loaded with ammonium glycyrrhizinate from Glycyrrhiza glabra showed no toxicity, good skin tolerability and improved the drug's anti-inflammatory activity in mice and human [61]. Psoralen from Fructus psoraleae loaded in ethosomes increased the lipid fluidity and cell membrane penetrability, which made it possible to enhance the skin deposition in vitro and in vivo and can be used to cure psoriasis [62]. Microemulsion gel-based systems of babchi oil (Psoralea corylifolia) and chitosan-coated microemulsions are a potential vehicle for the topical delivery of psoralen and methoxypsoralen (extracted from Ammi majus) for the treatment of psoriasis $[63,64]$. Microemulsion systems of $5 \%$ tea tree oil distilled from Melaleuca alternifolia are promising vehicles for a transdermal drug delivery [65]. Skin delivery of nanoemulsion system loaded turmeric oil (15\%) from Curcuma longa [66], nanoemulsion O/W containing rice bran oil [67], and nanoemulsion with glycyrrhetic acid from Glycyrrhiza glabra [68] significantly increased the transdermal permeability of these compounds, showed anti-inflammatory activities and a low irritation potential, and so can be used for psoriasis treatment. NLCs and SLNs showed a good ability to increase the drug accumulation in various skin layers. NLCs may as well be a more potent carrier for the topical delivery of capsaicin, to allow for an effective therapy of psoriasis [69].

\section{Mechanisms of Action of Herbal Products Used in Psoriasis Treatment}

In general, herbal products used in the treatment of psoriasis work by (1) inhibition of the keratinocyte hyperproliferation and induction of apoptosis, (2) inhibition of immune-inflammatory reactions, (3) suppression of phosphorylase kinase (PhK) activity, (4) inhibition of the hedgehog (Hh) signaling pathway.

A number of studies show that the inhibition of keratinocyte hyperproliferation, induction of apoptosis, and modulation of keratinocyte differentiation have been considered as targets of antipsoriatic strategies. Animal-based studies support the efficacy of the herbal products for the treatment of psoriasis via inhibition of keratinocyte hyperproliferation. The ethanolic extract of Aloe ve$r a$ leaf gel showed antipsoriatic activity by a significant differentiation of the epidermis, seen as orthokeratosis as well as an increase in the relative epidermal thickness when compared with the control group in mice [23]. The ethanolic extract of Nigella sativa seeds extract produced a significant epidermal differentiation from its degree of orthokeratosis comparable to tazarotene gel $(0.1 \%)$ in albino mice [24]. However, most desired for the treatment of psoriasis are herbal products that inhibit epidermal hyperplasia and inflammation simultaneously. Tuhuai extract reduced epidermal hyperplasia and inflammation in normal hairless mice, which makes it a valuable drug for treatment of psoriasis [70]. Baicalin isolated from Scutellaria baicalensis acts by inhibiting inflammatory reactions and inducing the differentiation of keratinocytes at the same time [29]. Moreover, baicalin cream (5\%) promotes epidermal differentiation and normal keratization of keratinocyte in mouse skin similar to tazarotene cream $(0.1 \%)$. The flavonoid quercetin from the rhizome of Smilax china shows significant orthokeratosis, reduction in epidermal thickness, anti-inflammatory, and maximum antiproliferant activities compared to mice treated with retinoic acid [26]. The treatment of psoriasis by inhibition of keratinocyte hyperproliferation through herbal products was also confirmed in clinical studies. Indigo naturalis ointment modulates the proliferation and differentiation of keratinocytes in the epidermis as well as inflammatory reactions by inhibiting the infiltration of $\mathrm{T}$ lymphocytes in patients with chronic plaque psoriasis [40]. Analysis of biopsies taken from patients after I. naturalis ointment treatment showed that the expressions of proliferating marker Ki-67 and inflammatory marker CD3 were decreased, while differentiation markers, such as filaggrin, were increased in the epidermis. Moreover, I. naturalis as well its major active constituent induribin inhibited the proliferation and abnormal differentiation of epidermal keratinocytes through decreasing proliferating cell nuclear antigen (PCNA) and increasing involucrin at both mRNA and protein levels in patients with psoriatic lesions [71].

Some studies show that the inhibition of fibroblast-secreted cytokines could regulate keratinocyte proliferation and differentiation as well slow down the process of inflammation in psoriasis [72]. Ethanolic extracts from Alpinia galanga, Curcuma longa and Annona squamosa showed effects on the downregulation of NF$\kappa \mathrm{B}$ signaling molecules in the HaCaT keratinocyte cell line, reflecting their potential use in treating diseases with inflammation and hyperproliferation such as psoriasis [73]. Copeifera langsdorffii oleoresin, also known as Copaiba balsam, exhibits an anti-inflammatory activity through inhibiting NF- $k$ B nuclear translocation and secreting proinflammatory cytokines [37]. Pre- 
incubation of LPS-stimulated human THP-1 monocytes with increasing concentrations of the oleoresin purified fraction reduced the release of proinflammatory cytokines (IL- $1 \beta$, IL-6, TNF- $\alpha$ ) and counteracts LPS-driven NF- $k$ B nuclear translocation. Water-soluble polysaccharide (GP-I) purified from Gynostemma pentaphyllum showed a significant antiproliferative effect and decreased TNF- $\alpha$, a vital proinflammatory cytokine in psoriasis [74]. Extracts of Acanthus mollis, Achillea ligustica, Artemisia arborescens, and Inula viscosa inhibited 5-LOX and COX-1 activity as well as NF- $k$ B activation [75]. Moreover, A. ligustica, A. arborescens, and $A$. mollis increased the biosynthesis of $15(S)-$ HETE, an anti-inflammatory eicosanoid. Herbal products treatment of psoriasis through inhibition of cytokines was also confirmed in animal-based studies. The topical application of a mixture of herbal extracts (Tinospora cordifolia, Curcuma longa, Celastrus paniculatus, Aloe vera) lead to the downregulation of overexpressed cytokines in mice, initially induced with psoriasis-like dermatitis through topical application of imiquimod [17]. Some research found that phosphorylase kinase ( $\mathrm{PhK}$ ) enzyme is expressed on a significantly higher level in psoriatic epidermis as in normal epidermis [76]. PhK integrates multiple calcium/calmodulin-dependent signaling pathways including those involved in cell migration and cell proliferation. Therefore, a modulation of PhK activity by drugs/herbal products may be an effective treatment of psoriasis. Curcumin is a selective PhK inhibitor [77]. It was observed that the PhK activity was highest in active untreated psoriasis, lower in the calcipotriol and curcumin treated group, and lowest in normal skin. A decreased PhK activity in curcumin and calcipotriol treated psoriasis patients was associated with corresponding decreases in keratinocyte transferrin receptor expression, severity of parakeratosis, and density of epidermal CD8+ T cells.

Some reports suggest that the Hh pathway is activated in lesional psoriatic skin, and that treatment with the Hh pathway antagonist cyclopamine may lead to a rapid resolution of the disease [78]. Cyclopamine isolated from Veratrum californicum was found to be more effective than topical clobetasol-17 propionate in the treatment of guttate and plaque type psoriasis [79]. Besides, inflammatory cells including CD4+ lymphocytes were found to disappear rapidly after the treatment with cyclopamine as well as hedgehog/smoothened signaling was inhibited. On the other hand, some research found that the Hh pathway is not activated in psoriasis [80]. It was observed that Hh target genes (PTCH1 and GLI1), whose expression is elevated in response to Hh signaling, were downregulated in lesional skin. Therefore, the proposed use of Hh antagonists as antipsoriatic agents is very questionable.

\section{Adverse Effects of Herbal Therapy}

The risk of adverse events increases with the topical administration and the long-term use of herbal-based formulations. Only few of the animal-based and clinical studies discussed above included a safety profile of herbal products. No side-effects or adverse events were reported for the psoriasis treatment with Aleurites moluccana oil [51], Curcuma longa microemulgel [42], Hypericum perforatum ointment [43], Indigo naturalis extract in oil [45], and Strobilanthes formosanus ointment [48] in patients participating in clinical trials. Local adverse events, mainly drying up, stinging, and itching of the skin on test areas, were observed after the topical application of Aloe vera gel $[36,52]$. The only clinical trial which verified the possibility of acute dermal toxicity showed that methanolic Cassia tora leaves extract incorporated in O/W creams was safe up to a dose of $2000 \mathrm{mg} / \mathrm{kg}$ [31]. Moreover, for human safety reasons the assessment of new substances is still evaluated for irritant potentials by application to animals followed by observation of visible changes such as erythema and oedema [81]. Testing for skin irritation in animals is not always predictive for humans, but is still the most widely used method in toxicity research for herbal extracts applied topically. It is well known that some herbal remedies may cause allergic reactions, erythema, and edema and several can be responsible for photosensitization [82,83]. Some herbal preparations can cause organ toxicity, hitting liver, kidneys, heart, and other organs [84-86], or possess cancerogenic properties [87]. Moreover, herbal products are often mislabeled (unknown purity and standardization of active constituents) and may contain additives or contaminants (heavy metals, pesticides) that are not listed in formulation [88$90]$. Some herbal products may interact with conventional drugs and some are toxic if used improperly or at to high doses [91]. Moreover, there are no regulations governing which herbal products can be marketed for various ailments as well as no authorities register adverse effects [92]. An increasing number of herbal formulation available for sale should prompt governments to introduce regulations on research which should be carried out before such products are released to the market.

\section{Challenges and Perspectives for the Treatment of Psoriasis by Herbal Products}

The review of the literature shows that a great growth has taken place in the worldwide interest in the potential of herbal medicines for the treatment of psoriasis over the last 20 years. Parallel to various synthetic medicines used topically (corticosteroids, vitamin D analogues, retinoids) and systemic (methotrexate, retinoids, cyclosporin), or targeted (biological) therapies (e.g. alefacept, efalizumab, etanercept) also herbal products play an important role as therapeutic agents for psoriasis treatment [93-95]. The long tradition of herbal products used in the treatment of many diseases is not sufficient to consider them as effective and safe drugs. To confirm their effectiveness as new promising alternative agent for the therapy of psoriasis a lot of research must be performed. Studies showing antiproliferative activity of herbal products and their ability to modulate cell differentiation in HaCaT cell lines [96-101] do not provide sufficient evidence that these herbal products will be effective in the treatment of psoriasis. Also promising results obtained in the studies performed on animals are not always consistent with the results of clinical trials. Therefore, only well-controlled double-blind clinical trials and toxicological studies can prove the efficacy and safety of herbal products in psoriasis treatment. In general, numerous difficulties associated with the evaluation of the efficacy and safety of herbal medicines, standardization of plant materials, and quality of herbal products cause that only a few herbal drugs have been approved for clinical applications so far, and finally reach the market [102]. Unfortunately, until now there are no approved herbal drugs dedicated for the treatment of psoriasis. However, in my opinion, the great progress in herbal medicine should make it possible that the first highly efficient and completely safe herbal product designed for the therapy of psoriasis will be available on the world market in the near future. Herbal products can make substantial contributions to drug innovation by providing novel chemical structures and/or multidirectional mechanisms of action, which are not commonly seen in synthetic compounds. The development of topical drug delivery systems facilitates plant extract penetration through the skin and enhances the 
therapeutic effects of herbal products in psoriasis treatment. Moreover, the growth of interest in natural medicine may force pharmaceutical companies to invest in extensive preclinical and well-controlled randomized clinical trials to prove the safety and efficacy of herbal medicines. Moreover, new branches of biological sciences, including pharmacogenomic, metabolomic, and microarray methodology, as well as the techniques of analytical chemistry, such as HPLC and GC/MS, would likely enable progress in the assessment of pharmacological qualities and safety of herbal products. These all allow for creating international guidelines that precisely define the requirements for studies about the use of herbal medicine. It seems that establishing global regulatory mechanisms for the introduction of herbal drugs to the world market is desirable and necessary.

\section{Conclusion}

Herbal products are being increasingly used in the treatment of skin diseases like psoriasis. Some of them specifically inhibit epidermal hyperplasia and/or inflammation, which can be widely used to treat psoriasis. Unfortunately, most studies provide only limited information about the efficacy and safety of topically used herbal products in the treatment of psoriasis. Therefore, more scientific evidence and documentation is desired for the promotion of herbal treatment of psoriasis, which must be substantiated by reliable clinical trials with standardized materials and formulations.

\section{Conflict of Interest}

\section{$\checkmark$}

We confirm that there are no known conflicts of interest associated with this publication and there has been no significant financial support for this work that could have influenced its outcome.

\section{References}

1 Lowes MA, Bowcock AM, Krueger JG. Pathogenesis and therapy of psoriasis. Nature 2007; 445: 866-873

2 Rahman M, Alam K, Ahmad MZ, Gupta G, Afzal M, Akhter S, Kazmi I, Ahmad FJ, Anwar F. Classical to current approach for treatment of psoriasis: a review. Endocr Metab Immune Disord Drug Targets 2012; 12 : 287-302

3 Yuqi TT. Review of a treatment for psoriasis using herose, a botanical formula. J Dermatol 2005; 32: 940-945

4 Traub M, Marshall K. Psoriasis-pathophysiology, conventional, and alternative approaches to treatment. Altern Med Rev 2007; 12: 319-330

5 Griffiths CE, Barker JN. Pathogenesis and clinical features of psoriasis. Lancet 2007; 370: 263-271

6 Keseroglu HO, Gönül M. Traditional topical herbal therapies in psoriasis. TANG 2014; 4: 13-20

7 Johnson-Huang LM, Lowes MA, Krueger JG. Putting together the psoriasis puzzle: an update on developing targeted therapies. Dis Model Mech 2012; 5: 423-433

8 Bruch-Gerharz D, Schnorr O, Suschek C, Beck KF, Pfeilschifter J, Ruzicka T, Kolb-Bachofen V. Arginase 1 overexpression in psoriasis: limitation of inducible nitric oxide synthase activity as a molecular mechanism for keratinocyte hyperproliferation. Am J Pathol 2003; 162: 203-211

9 Ghadially R, Reed JT, Elias PM. Stratum corneum structure and function correlates with phenotype in psoriasis. J Invest Dermatol 1996; 107: 558-564

10 Katare OP, Raza K, Singh B, Dogra S. Novel drug delivery systems in topical treatment of psoriasis: Rigors and vigors. Indian J Dermatol Venereol Leprol 2010; 76: 612-621

11 Gudjonsson JE, Johnston A, Sigmundsdottir H, Valdimarsson H. Immunopathogenic mechanisms in psoriasis. Clin Exp Immunol 2004; 135: 1-8
12 Nickoloff BJ, Nestle FO. Recent insights into the immunopathogenesis of psoriasis provide new therapeutic opportunities. J Clin Invest 2004; 113: $1664-1675$

13 Chamian F, Lowes MA, Lin SL, Lee E, Kikuchi T, Gilleaudeau P, SullivanWhalen M, Cardinale I, Khatcherian A, Novitskaya I, Wittkowski KM, Krueger JG. Alefacept reduces infiltrating T cells, activated dendritic cells, and inflammatory genes in psoriasis vulgaris. Proc Natl Acad Sci U S A 2005; 102: 2075-2080

14 Lowes MA, Chamian F, Abello MV, Fuentes-Duculan J, Lin SL, Nussbaum $R$, Novitskaya I, Carbonaro H, Cardinale I, Kikuchi T, Gilleaudeau P, Sullivan-Whalen M, Wittkowski KM, Papp K, Garovoy M, Dummer W, Steinman RM, Krueger JG. Increase in TNF-alpha and inducible nitric oxide synthase-expressing dendritic cells in psoriasis and reduction with efalizumab (anti-CD11a). Proc Natl Acad Sci U S A 2005; 102: 19057-19062

15 Quin JZ, Chaturvedi V, Denning MF, Choubey D, Diaz MO, Nickoloff BJ. Role of NF-kappaB in the apoptotic-resistant phenotype of keratinocytes. J Biol Chem 1999; 274: 37957-37964

16 Ruckert R, Asadullah K, Seifert M, Budagian VM, Arnold R, Trombotto C, Paus $R$, Bulfone-Paus $S$. Inhibition of keratinocyte apoptosis by IL-15: a new parameter in the pathogenesis of psoriasis? J Immunol 2000; 165: 2240-2250

17 Arora N, Shah K, Pandey-Rai S. Inhibition of imiquimod-induced psoriasis-like dermatitis in mice by herbal extracts from some Indian medicinal plants. Protoplasma 2016; 253: 503-515

18 Lowes MA, Suárez-Fariñas M, Krueger JG. Immunology of psoriasis. Annu Rev Immunol 2014; 32: 227-255

19 Goldminz AM, Au SC, Kim N, Gottlieb AB, Lizzul PF. NF-кB: an essential transcription factor in psoriasis. J Dermatol Sci 2013; 69: 89-94

20 Johansen C, Flindt E, Kragballe K, Henningsen J, Westergaard $M$, Kristiansen $K$, Iversen $L$. Inverse regulation of the nuclear factor-kappaB binding to the p53 and interleukin- 8 kappaB response elements in lesional psoriatic skin. J Invest Dermatol 2005; 124: 1284-1292

21 Singh KK, Tripathy S. Natural treatment alternative for psoriasis: a review on herbal resources. J App Pharm Sci 2014; 4: 114-121

22 Jarrett A, Spearman RIG. Psoriasis. In: Taverner D, Trounce J, eds. Histochemistry of the Skin. London: University Press; 1964

23 Dhanabal SP, Priyanka Dwarampudi L, Muruganantham N, Vadivelan $R$. Evaluation of the antipsoriatic activity of Aloe vera leaf extract using a mouse tail model of psoriasis. Phytother Res 2012; 26: 617-619

24 Dwarampudi LP, Palaniswamy D, Nithyanantham M, Raghu PS. Antipsoriatic activity and cytotoxicity of ethanolic extract of Nigella sativa seeds. Pharmacogn Mag 2012; 8: 268-272

25 Lin ZX, Jiao BW, Che CT, Zuo Z, Mok CF, Zhao M, Ho WK, Tse WP, Lam KY, Fan $R Q$ Yang $Z$ J, Cheng $C H$. Ethyl acetate fraction of the root of Rubia cordifolia $\mathrm{L}$. inhibits keratinocyte proliferation in vitro and promotes keratinocyte differentiation in vivo: potential application for psoriasis treatment. Phytother Res 2010; 24: 1056-1064

26 Vijayalakshmi A, Ravichandiran V, Velraj M, Nirmala S, Jayakumari S. Screening of flavonoid "quercetin" from the rhizome of Smilax china Linn. for anti-psoriatic activity. Asian Pac J Trop Biomed 2012; 2: 269275

27 Shrivastav S, Sindhu R, Kumar S, Kumar P. Anti-psoriatic and phytochemical evaluation of Thespesia populnea bark extracts. Int J Pharm Pharm Sci 2009; 1: 176-185

28 Raj BA, Muruganantham N, Praveen TK, Raghu PS. Screening of Wrightia tinctoria leaves for anti psoriatic activity. Hygeia J Drug Med 2012; 4: 73-78

$29 \mathrm{Wu}$ J, Li H, Li M. Effects of baicalin cream in two mouse models: 2,4-dinitrofluorobenzene-induced contact hypersensitivity and mouse tail test for psoriasis. Int J Clin Exp Med 2015; 8: 2128-2137

30 Oyedeji FO, Bankole-Ojo OS. Quantitative evaluation of the antipsoriatic activity of sausage tree (Kigelia africana). Afr J Pure Appl Chem 2012; 6: 214-218

31 Singhal M, Kansara N. Cassia tora Linn cream inhibits ultraviolet-Binduced psoriasis in rats. ISRN Dermatol 2012; 2012: 346510

32 Nagakuma H, Kambara T, Yamamoto T. Rat ultraviolet ray B photodermatitis: an experimental model of psoriasis vulgaris. Int J Exp Pathol 1995; 76: 65-73

33 Divakara P, Nagaraju B, Buden RP, Sekhar HS, Ravi CM. Antipsoriatic activity of ayurvedic ointment containing aqueous extract of the bark of Pongamia pinnata using the rat ultraviolet ray photodermatitis model. Adv Med Plant Res 2013; 1: 8-16

34 Gulliver WP, Donsky HJ. A report on three recent clinical trials using Mahonia aquifolium $10 \%$ topical cream and a review of the worldwide 
clinical experience with Mahonia aquifolium for the treatment of plaque psoriasis. Am J Ther 2005; 12: 398-406

35 Koo J, Arain S. Traditional Chinese medicine in dermatology. Clin Dermatol 1999; 17: 21-27

36 Choonhakarn C, Busaracome P, Sripanidkulchai B, Sarakarn P. A prospective, randomized clinical trial comparing topical aloe vera with $0.1 \%$ triamcinolone acetonide in mild to moderate plaque psoriasis. J Eur Acad Dermatol Venereol 2010; 24: 168-172

37 Gelmini F, Beretta G, Anselmi C, Centini M, Magni P, Ruscica M, Cavalchini A, Facino RM. GC-MS profiling of the phytochemical constituents of the oleoresin from Copaifera langsdorffii Desf. and a preliminary in vivo evaluation of its antipsoriatic effect. Int J Pharm 2013; 440: 170-178

38 Stücker M, Memmel U, Hoffmann M, Hartung J, Altmeyer P. Vitamin B (12) cream containing avocado oil in the therapy of plaque psoriasis. Dermatology 2001; 203: 141-147

39 Syed TA, Ahmad SA, Holt AH, Ahmad SA, Ahmad SH, Afzal M. Management of psoriasis with Aloe vera extract in a hydrophilic cream: a placebo-controlled, double-blind study. Trop Med Int Health 1996; 1: 505-509

40 Lin YK, Wong WR, Chang YC, Chang CJ, Tsay PK, Chang SC, Pang JH. The efficacy and safety of topically applied Indigo naturalis ointment in patients with plaque-type psoriasis. Dermatology 2007; 214: 155-161

41 Wang A, Liu Z, Liu S. Treatment of psoriasis vulgaris with lacquer made of Camptotheca acuminata nuts. J Clin Dermatol 1998; 27: 243-244

42 Sarafian G, Afshar M, Mansouri P, Asgarpanah J, Raoufinejad K, Rajabi M. Topical turmeric microemulgel in the management of plaque psoriasis; A clinical evaluation. Iran J Pharm Res 2015; 14: 865-876

43 Najafizadeh P, Hashemian F, Mansouri P, Farshi S, Surmaghi MS, Chalangari R. The evaluation of the clinical effect of topical St Johns wort (Hypericum perforatum L.) in plaque type psoriasis vulgaris: a pilot study. Australas J Dermatol 2012; 53: 131-135

44 Lin YK, Yen HR, Wong WR, Yang SH, Pang JHS. Successful treatment of pediatric psoriasis with Indigo naturalis composite ointment. Pediatr Dermatol 2006; 23: 507-510

45 Lin YK, See LC, Huang YH, Chang YC, Tsou TC, Lin TY, Lin NL. Efficacy and safety of Indigo naturalis extract in oil (Lindioil) in treating nail psoriasis: a randomized, observer-blind, vehicle-controlled trial. Phytomedicine 2014; 21: 1015-1020

46 Bernstein S, Donsky H, Gulliver W, Hamilton D, Nobel S, Norman R. Treatment of mild to moderate psoriasis with Relieva, a Mahonia aquifolium extract - a double-blind, placebo-controlled study. Am J Ther 2006; 13 : $121-126$

47 Wiesenauer M, Lüdtke R. Mahonia aquifolium in patients with psoriasis vulgaris - an intraindividual study. Phytomedicine 1996; 3: 231-235

48 Lin YK, Chang CJ, Chang YC, Wong WR, Chang SC, Pang JHS. Clinical assessment of patients with recalcitrant psoriasis in a randomized, observer-blind, vehicle-controlled trial using Indigo naturalis. Arch Dermatol 2008; 144: 1457-1464

49 Bernstein JE, Parish LC, Rapaport M, Rosenbaum MM, Roenigk HH Jr. Effects of topically applied capsaicin on moderate and severe psoriasis vulgaris. J Am Acad Dermatol 1986; 15: 504-507

50 Augustin M, Andrees U, Grimme H, Schöpf E, Simon J. Effects of Mahonia aquifolium ointment on the expression of adhesion, proliferation, and activation markers in the skin of patients with psoriasis. Forsch Komplementarmed 1999; 6: 19-21

51 Brown AC, Koett J, Johnson DW, Semaskvich NM, Holck P, Lally D, Cruz L, Young R, Higa B, Lo S. Effectiveness of kukui nut oil as a topical treatment for psoriasis. Int J Dermatol 2005; 44: 684-687

52 Paulsen E, Korsholm L, Brandrup F. A double-blind, placebo-controlled study of a commercial Aloe vera gel in the treatment of slight to moderate psoriasis vulgaris. J Eur Acad Dermatol Venereol 2005; 19: 326331

53 Thomas J, Narkowicz CK, Jacobson GA, Peterson GM. Safety and efficacy of kunzea oil-containing formulations for the management of psoriasis: a randomized, controlled trial. J Clin Pharm Ther 2015; 40: 566572

54 Suresh PK, Singh P, Saraf S. Novel topical drug carriers as a tool for treatment of psoriasis: progress and advances. Afr J Pharm Pharmacol 2013; 7: $138-147$

55 Pradhan M, Singh D, Singh MR. Novel colloidal carriers for psoriasis: current issues, mechanistic insight and novel delivery approaches. J Control Release 2013; 170: 380-395

56 Saraf S. Applications of novel drug delivery system for herbal formulations. Fitoterapia 2010; 81: 680-689
57 Singh MR, Nag MK, Patel S, Daharwal SJ, Singh D. Novel approaches for dermal and transdermal delivery of herbal drugs. Res J Pharmacog Phytochem 2013; 5: 271-279

58 Nagle A, Goyal AK, Kesarla R, Murthy RSR. Efficacy study of vesicular gel containing methotrexate and menthol combination on parakeratotic rat skin model. J Liposome Res 2011; 21: 134-140

59 Singh HP, Utreja P, Tiwary AK, Jain S. Elastic liposomal formulation for sustained delivery of colchicine: in vitro characterization and in vivo evaluation of anti-gout activity. AAPS J 2009; 11: 54-64

60 Gupta R, Gupta M, Mangal S, Agrawal U, Vyas SP. Capsaicin-loaded vesicular systems designed for enhancing localized delivery for psoriasis therapy. Artif Cells Nanomed Biotechnol 2016; 44: 825-834

61 Marianecci C, Rinaldi F, Mastriota M, Pieretti S, Trapasso E, Paolino D, Carafa $M$. Anti-inflammatory activity of novel ammonium glycyrrhizinate/niosomes delivery system: Human and murine models. J Control Release 2012; 164: 17-25

62 Zhang YT, Shen LIN, Zhao JH, Feng NP. Evaluation of psoralen ethosomes for topical delivery in rats by using in vivo microdialysis. Int J Nanomedicine 2014; 9: 669-678

63 Ali J, Akhtar N, Sultana Y, Baboota S, Ahuja A. Antipsoriatic microemulsion gel formulations for topical drug delivery of babchi oil (Psoralea corylifolia). Methods Find Exp Clin Pharmacol 2008; 30: 277-285

64 Behera J, Keservani RK, Yadav A, Tripathi M, Chadoker A. Methoxsalen loaded chitosan coated microemulsion for effective treatment of psoriasis. Int J Drug Deliv 2010; 2: 159-167

65 Khokhra S, Diwan A. Microemulsion based transdermal drug delivery of tea tree oil. Int J Drug Dev Res 2011; 3: 191-198

66 Ali MS, Alam MS, Imam FI, Siddiqui MR. Topical nanoemulsion of turmeric oil for psoriasis: characterization, ex vivo and in vivo assessment. Int J Drug Deliv 2012; 4: 184-197

67 Bernardi DS, Pereira TA, Maciel NR, Bortoloto J, Viera GS, Oliveira GC, Rocha-Filho PA. Formation and stability of oil-in-water nanoemulsions containing rice bran oil: In vitro and in vivo assessments. J Nanobiotechnology 2011; 9: 1-9

68 Puglia C, Rizza L, Drechsler M, Bonina F. Nanoemulsions as vehicles for topical administration of glycyrrhetic acid: characterization and in vitro and in vivo evaluation. Drug Deliv 2010; 17: 123-129

69 Agrawal U, Gupta M, Vyas SP. Capsaicin delivery into the skin with lipidic nanoparticles for the treatment of psoriasis. Artif Cells Nanomed Biotechnol 2013; 43: 33-39

70 Man MQ Shi Y, Man M, Lee SH, Demerjian M, Chang S, Feingold KR, Elias $P M$. Elias Chinese herbal medicine (Tuhuai extract) exhibits topical anti-proliferative and anti-inflammatory activity in murine disease models. Exp Dermatol 2008; 17: 681-687

71 Lin YK, Leu YL, Yang SH, Chen HW, Wang CT, Pang JH. Anti-psoriatic effects of Indigo naturalis on the proliferation and differentiation of keratinocytes with indirubin as the active component. J Dermatol Sci 2009; 54: 168-174

72 Zhang H, Gu J. Progress of experimental study on treatment of psoriasis by Chinese medicinal monomer and single or compound recipe in Chinese materia medica. Chin J Integr Med 2007; 13: 312-316

73 Saelee C, Thongrakard V, Tencomnao T. Effects of Thai medicinal herb extracts with anti-psoriatic activity on the expression on NF- $k \mathrm{~B}$ signaling biomarkers in HaCaT keratinocytes. Molecules 2011; 16: 39083932

74 Li XL, Wang ZH, Zhao YX, Luo SJ, Zhang DW, Xiao SX, Peng ZH. Purification of a polysaccharide from Gynostemma pentaphyllum Makino and its therapeutic advantages for psoriasis. Carbohydr Polym 2012; 89: 1232-1237

75 Bader A, Martini F, Schinella GR, Rios JL, Prieto JM. Modulation of Cox-1, 5-, 12- and 15-Lox by popular herbal remedies used in southern Italy against psoriasis and other skin diseases. Phytother Res 2015; 29: 108113

76 Heng MCY, Song MK, Heng MK. Elevated phosphorylase kinase activity in psoriatic epidermis: correlation with increased phosphorylation and psoriatic activity. Br J Dermatol 1994; 130: 298-306

77 Heng MC, Song MK, Harker J, Heng MK. Drug-induced suppression of phosphorylase kinase activity correlates with resolution of psoriasis as assessed by clinical, histological and immunohistochemical parameters. Br J Dermatol 2000; 143: 937-949

78 Hovhannisyan A, Matz M, Gebhardt R. From teratogens to potential therapeutics: natural inhibitors of the Hedgehog signaling network come of age. Planta Med 2009; 75: 1371-1380 
79 Taş S, Avci O. Rapid clearance of psoriatic skin lesions induced by topical cyclopamine. A preliminary proof of concept study. Dermatology 2004; 209: 126-131

80 Gudjonsson JE, Aphale A, Grachtchouk M, Ding J, Nair RP, Wang T, Voorhees JJ, Dlugosz AA, Elder JT. Lack of evidence for activation of the hedgehog pathway in psoriasis. J Invest Dermatol 2009; 129: 635-640

81 Welss T, Basketter DA, Schröder KR. In vitro skin irritation: facts and future. State of the art review of mechanisms and models. Toxicol In Vitro 2004; 18: 231-243

82 Ernst E. Adverse effects of herbal drugs in dermatology. Br J Dermatol 2000; 143: 923-929

83 De Smet PA. Health risks of herbal remedies: an update. Clin Pharmacol Ther 2004; 76: 1-17

84 Asif $M$. A brief study of toxic effects of some medicinal herbs on kidney. Adv Biomed Res 2012; 1: 44

85 Dwivedi S, Aggarwal A, Sharma V. Cardiotoxicity from 'safe' herbomineral formulations. Trop Doct 2011; 41: 113-115

86 Stedman C. Herbal hepatotoxicity. Semin Liver Dis 2001; 22: 195-206

87 Bode AM, Dong Z. Toxic phytochemicals and their potential risks for human cancer. Cancer Prev Res 2015; 8: 1-8

88 Niggemann B, Grüber C. Side-effects of complementary and alternative medicine. Allergy 2003; 58: 707-716

89 Huxtable RJ. The myth of beneficent nature: the risks of herbal preparations. Ann Intern Med 1992; 117: 165-166

90 Joshi BS, Kaul PN. Alternative medicine: herbal drugs and their critical appraisal - Part I. Prog Drug Res 2001; 56: 1-76

91 Zhou SF, Zhou ZW, Li CG, Chen X, Yu X, Xue CC, Herington A. Identification of drugs that interact with herbs in drug development. Drug Discov Today 2007; 12: 664-673

92 Bedi MK, Shenefelt PD. Herbal therapy in dermatology. Arch Dermatol 2002; 138: 232-242

93 Lebwohl M, Ting PT, Koo JYM. Psoriasis treatment: traditional therapy. Ann Rheum Dis 2005; 64: 83-86
94 Weger W. Current status and new developments in the treatment of psoriasis and psoriatic arthritis with biological agents. $\mathrm{Br}$ J Pharmacol 2010; 160: 810-820

95 Deng S, May BH, Zhang AL, Lu C, Xue CC. Topical herbal medicine combined with pharmacotherapy for psoriasis: a systematic review and meta-analysis. Arch Dermatol Res 2013; 305: 179-189

96 Tse WP, Cheng CHK, Che CT, Zhao M, Lin ZX. Induction of apoptosis underlies the Radix Rubiae-mediated anti-proliferative action on human epidermal keratinocytes: Implications for psoriasis treatment. Int J Mol Med 2007; 20: 663-672

97 Mok CF, Xie CM, Sham KWY, Lin ZX, Cheng CHK. 1,4-dihydroxy-2-naphthoic acid induces apoptosis in human keratinocyte: potential application for psoriasis treatment. Evid Based Complement Alternat Med 2013; 2013: 792840

98 Li FL, Xu R, Zeng QC, Li X, Chen J, Wang YF, Fan B, Geng L, Li B. Tanshinone IIA inhibits growth of keratinocytes through cell cycle arrest and apoptosis: underlying treatment mechanism of psoriasis. Evid Based Complement Alternat Med 2012; 2012: 927658

99 Zhou LL, Lin ZX, Fung KP, Cheng CH, Che CT, Zhao M, Wu SH, Zuo Z. Celastrol-induced apoptosis in human HaCaT keratinocytes involves the inhibition of NF- $k$ B activity. Eur J Pharmacol 2011; 670: 399-408

100 Sampson JH, Raman A, Karlsen G, Navsaria H, Leigh IM. In vitro keratinocyte antiproliferant effect of Centella asiatica extract and triterpenoid saponins. Phytomedicine 2001; 8: 230-235

101 Wilkinson JD, Williamson EM. Cannabinoids inhibit human keratinocyte proliferation through a non-CB1/CB2 mechanism and have a potential therapeutic value in the treatment of psoriasis. J Dermatol Sci 2007; 45: 87-92

102 Calixto JB. Efficacy, safety, quality control, marketing and regulatory guidelines for herbal medicines (phytotherapeutic agents). Braz J Med Biol Res 2000; 33: 179-189 